\title{
Contribution of Agriculture Sector in the GDP Growth Rate of Pakistan
}

\section{Usman $\mathbf{M}^{*}$}

Department of commerce, University of Central Punjab, Pakistan

\begin{abstract}
This study is about to be the contribution of agriculture sector in the GDP growth rate of Pakistan. The important variables of this study is major crops, live stocks, other crops which is contribute in the agriculture sector and after that study also provide the results of whole contribution of agriculture sector in the GDP growth rate of Pakistan. Most of this study is based on secondary data and study has taken 25 years past data from economic survey of Pakistan and the period is (1990-2014). For justifying their results researcher fit the regression model for this study. Our results show that there is a strong relationship in our variables agriculture sector and GDP growth rate. Research also provides the significant impact of Major crops and other crops on agriculture sector and contribution towards (GDP) Gross Domestic Product. Live-stock is also major part of agriculture and has significant contribution in agriculture sector.
\end{abstract}

Keywords: Gross domestic product; Agriculture contribution; Major crops; Live stock; Other crops

\section{Introduction}

Agriculture sector is a exclusive sector in which our modes of life and our business enterprise are combine together. Agriculture sector is the most important part of the economy of Pakistan. Agriculture sector is contributing almost $23.4 \%$ in the economy of Pakistan. Main focus of agriculture sector is provision of food security for our people relatively the maximization of production. It gives us livelihood and makes connectivity within the country. Approximately $70 \%$ of total population of Pakistan lives in rural areas. Almost $45 \%$ of work force is engaged with agriculture sector. Pakistan provincial government pays attention on priority bases to raise the productivity of agriculture sector of Pakistan. Agriculture is a main sector for the provision of raw material to the downstream industry for production. The fundamental role of agriculture sector is to minimizing poverty, provide employment opportunity which is country really desire. Main Purpose of our agriculture sector is to diversify it from self-reliance to profitability.

Unfortunately, Pakistan based on conservative method for production and also based on self- reliance which is main cause for low productivity. Most of the developed countries use advanced technology and go to maximize per acre productivity. When per acre productivity is low its mean that lower of former profit and when farmer did not earn more profit then they have not excess money to purchase high quality seeds, better pesticides, advanced technology due to lack of these things next productivity is also lower and this vicious circle is continue.

Pakistan major crops are wheat, rice, maize, sugarcane and cotton. Contribution of major crops in agriculture sector is about to be $25.6 \%$ and contribution of major crops in GDP is almost 5.4\% according to the economic survey of Pakistan. Wheat participate in contribution of agriculture is approximately $10.3 \%$ and in l GDP is $2.2 \%$. Rice is cash plus a food crop. Pakistan produces high quality rice which is best and like in all over the world. Pakistan have specialty in but due to some inherent problem we have not excess on expertise to making export on a lot of quantity of good rice that is eventually effects on our foreign exchange reserve. Share of rice in our agriculture is almost $3.1 \%$ and in GDP is $0.7 \%$. The Cotton is a cash crop and make raw material for our textile industry and contribution in GDP is almost $1.4 \%$. Sugarcane is also a cash crop and also food crop. Our sugar industry is based on raw material of sugarcane. Sugarcane contribute in agriculture sector is $3.4 \%$ and in GDP is $0.7 \%$.Our minor crops involves pulses, mustard, gram, jawar, bajra, oil seeds and barley. Minor crops contributing in agriculture sector is $11.6 \%$.
Pakistan Irrigation system is one of the largest systems in all over the world. Pakistan irrigation system stretches in whole Pakistan. Irrigation system is necessary for productive crop growing to establish sustainable growth. Approximately three fourth of the land is cultivated under this largest canal system. Canal system is a substitute for the shortage of rainfall.

Agricultural credit is also a most important prop of growth in agricultural sector. Success for any business credit plays a pivotal role. Governments take steps for provision of agriculture credit to the people in the rural areas to the purpose of ornamental the production. Agriculture credit makes an opportunity to improve the production by access of technology and also efficient labor. Now approximately 3950 bank branches in Pakistan are working to facilitate the farmers with agriculture credit. Punjab provincial cooperative bank limited, seven commercial banks, Zaraie Taraqiati bank limited, and three Islamic banks which is providing agricultural credit. It is important to mention that approximately 380 billion Rupees are reserves for agricultural in the year of 2013-14 and achieved its target $67.3 \%$ of that amount.

Livestock is one important element of agriculture sector. The Livestock provides us milk, meat and yogurt to the community. Continuous Growth in live-stock is increasing and it becomes an ideal sector for diminution of poverty specially in rural areas.

\section{Literature Review}

Ministry of Agriculture, Raza, Ali, and Mehboob, Agriculture Sector is Major sector of the economy [1-3]. Approximately $63 \%$ of livelihood is connected with this sector over total population. Population which lived in villages is connected with agriculture. Ministry of Finance. About to be $43 \%$ of labor rule and $21 \%$ of GDP Growth is achieved from this sector. Basically Agriculture sector is a sector which is producing the primary raw material for other sector of economy for growth [4]. Worldbank.org, accordingly, to the World Bank report Pakistan GDP is dollar 161.99 in millions [5]. Zaman, Khan, and Ahmad in their research included the variables in agriculture major crops, minor crops, livestock, fisheries, and poultry etc. [6].

*Corresponding author: Usman M, Department of commerce, University of Central Punjab, Pakistan, Tel: 924235880007; E-mail: usman.mustafa49@ucp.edu.pk

Received January 22, 2016; Accepted March 29, 2016; Published April 04, 2016

Citation: Usman M (2016) Contribution of Agriculture Sector in the GDP Growth Rate of Pakistan. J Glob Econ 4: 184. doi:10.4172/2375-4389.1000184

Copyright: (c) 2016 Usman M. This is an open-access article distributed under the terms of the Creative Commons Attribution License, which permits unrestricted use, distribution, and reproduction in any medium, provided the original author and source are credited. 
Adnan Hye, Malik research Include credit bases and also highlight the increasing growth in easy and deviant availability of agriculture credit is main the theme of growth $[7,8]$. SBP according to the report of state bank of Pakistan total Agriculture credit is about 380 billion and 275 Billion is collecting for the growth of Agriculture Sector [9].

Adnan Hye QM, include livestock is a back bone of agriculture. According to this research livestock help to minimizing the poverty of people. Livestock provide the base of food supply and also provide the beneficial earning for the formers $[10,11]$. Livestock make electricity of income and change the standard of living [12]. Livestock provide the income on daily basis to meet the daily needs. Livestock reduced the poverty and inequality distribution of income. Major portion of Agriculture comes from livestock to full fill the current and future need. Economic Survey of Pakistan livestock contribute $55.91 \%$ of Agriculture value addition products and Growth in the livestock $2.88 \%$ as previous year 3.99 and decline $1.11 \%$ [13].

Bhatti, Suttinon and Nasu, Govt of Pakistan Irrigation and water is basic necessary of Agriculture Sector [14,15]. Some developing countries have lack of renovation of fresh water. Irrigation system consumes $79 \%$ of all available water. This is vulnerable situation of Asia [16]. ADB there is problem of increase in water and irrigation because many rivers the works at their toll capacity [17].GOP irrigation system does not full the need of agriculture [18]. Goverment of Punjab, there is need of time that to build new dams and reserve for water [19]. In Pakistan the lack is increase because there is no efficient methods adopted use the water however this Govt. of the Punjab is increasingly because Agriculture increased and rivers don't maintain their flow [15].

Haq, Gheblawi and Muhammad, Aslam, Problems in Agricuture of Pakistan in this research researcher include the variable major crops wheat rice, cotton, maize. Major portion of total Agriculture is received from Major crops [20,21]. These productions provide the foreign exchange for the country due to export. Economic Survey Of Pakistan major crops Add $25.6 \%$ of value addition in GDP and over all addition in agriculture is $5.41 \%$ to GDP [13]. Minor crops are jawar bajra, muskrat, poolers, onion garlic, chili potato $[22,23]$. Due to decline in minor crops and vegetables is cause to increase in production of other major crops. Include that 11.6 of value add [24].

Economic Survey Of Pakistan, fisheries and poultry contribute $1.3 \%$ Growth in GDP and contribution is livestock $10.8 \%$ and $6.1 \%$ in agriculture according to economic survey of Pakistan [13].

\section{Theoretical Framework}

Participants contribution\% in agriculture sector is given in Figure 1.

\section{Hypothesis}

Ho: Agriculture sector has significant contribution in GDP growth of Pakistan.

$\mathrm{H}_{1}$. Agriculture has not significant contribution in GDP growth of Pakistan.

Ho: Major crops have significant impact on agriculture contribution towards GDP

$\mathrm{H}_{1}$ : Major crops have not significantly impact on agriculture contribution towards GDP.

Ho: Other crops have significantly impacts on agriculture contribution towards GDP.
$\mathrm{H}_{1}$ : Other crops have not significantly impact on agriculture contribution towards GDP.

Ho: Live-stock significantly impact on agriculture contribution towards GDP.

$\mathrm{H}_{1}$ : live stock has not significantly impact on agriculture contribution towards GDP.

\section{Methodology}

The data is Time series of all the variables and taken over the Duration of 1990-2014. This data is approximately 25 years past. Main source of data is Economic survey of Pakistan, State Banks of Pakistan, would Bank of Pakistan, Pak. Bureau of Statistics and Federal Budget of Pakistan. The relationship of our variables is about annual growth rate in the Agriculture sector of Pakistan with GDP Growth rate of Pakistan. For the purpose of testing of Hypotheses Researcher fit the regression model for reject the Ho or accept the Ho. In our research we also analyze the descriptive statistic for analyzing of our data.

In Above the Table 1 shows the descriptive statistic of GDP growth of Pakistan, agriculture growth of Pakistan, Major crops growth of Pakistan, Minor crop growth of Pakistan and live-stock growth of Pakistan. In Average growth rate of GDP is $4.54 \%$ and our current growth rate in GDP is $4.14 \%$ which is dreadfully lower even below then average. Maximum growth in GDP is $8.40 \%$ which is the year of 2005 and minimum growth rate in GDP is .36\% which is the year of 2001. However means of GDP of growth rate of agriculture sector is 5.10 and Minimum is -3.49 which shows that decrease in growth rate of agriculture sector will cause for decrease in GDP growth rate of Pakistan and maximum growth rate is $24.20 \%$, average growth rate of Major crops is $4.85 \%$ and currently growth rate of Major crop is $3.7 \%$ and this is less than the average growth, minimum growth rate in Major Crops of Pakistan is $-12 \%$ and maximum is $37.26 \%$. The Mean of other crop is $4.13 \%$. The mean of live-stock is $8.15 \%$ and our current growth rate is also lower than average growth and we need to be improvements (Table 2)

For agriculture sector, $\mathrm{P}-\mathrm{V}$ alue is less than 0.05 which demonstrate that there is a significant contribution of agriculture sector in the growth rate of Gross Domestic Product. According to this results if agriculture sector grow its capacity building, provide incentive to farmers and availability of pesticides to increase the productivity will cause the significant contribution in GDP (Table 3).

In Above table we shows, that major crops has P-value less than the 0.05 which shows that major crops has significantly impact on agriculture growth towards GDP. Likewise, other crops also P-value less than the 0.05 which is the element of significant result. Live-stock has significant impacts in GDP growth of Pakistan.

\section{Limitation of the Study}

Our study limitation is that time for this study is approximately two months that's why our major focus on secondary data and this data taken from Government of the Punjab, Economic survey of Pakistan and State Bank of Pakistan.

\section{Conclusion}

Our objective about this research is examining the effects of agriculture on GDP growth rate in the area of Pakistan in the duration of 1990-2014. It is also proved that in developing of agriculture is optimistically depend on major crops, other crops, forestry, fisheries, 


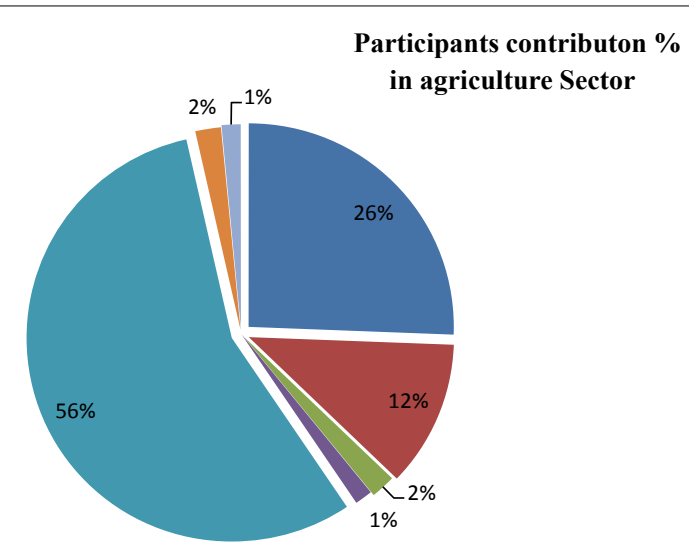

Major Crop

Minor Crop

Other Crop

Agri Credit

- Livestock

Fisheries

Forestry

Figure 1: Participants contribution $\%$ in agriculture sector.

\begin{tabular}{|c|c|c|c|c|c|}
\hline Variables & $\mathbf{N}$ & Mean & $\begin{array}{c}\text { Standard } \\
\text { deviation }\end{array}$ & Minimum & Maximum \\
\hline $\begin{array}{c}\text { Gross domestic product } \\
\text { growth rate }\end{array}$ & 25 & $4.54 \%$ & 1.77 & $.36 \%$ & $8.40 \%$ \\
\hline Agriculture growth rate & 25 & $5.10 \%$ & 6.39 & $-3.89 \%$ & $24.20 \%$ \\
\hline Major crops growth rate & 25 & $4.85 \%$ & 9.36 & $-12.25 \%$ & $37.26 \%$ \\
\hline Other crops & 25 & $4.13 \%$ & 9.65 & $-4 \%$ & $47 \%$ \\
\hline Live stock & 25 & $8.33 \%$ & 10.78 & $1.21 \%$ & $46.80 \%$ \\
\hline
\end{tabular}

Every variable is containing per year growth rate.

Table 1: Descriptive statistics.

\begin{tabular}{|c|c|c|c|c|c|}
\hline \multirow[t]{2}{*}{ Model } & \multicolumn{2}{|c|}{$\begin{array}{l}\text { Unstandardized } \\
\text { Coefficients }^{\mathrm{a}}\end{array}$} & \multirow{2}{*}{$\begin{array}{c}\text { Standardized } \\
\text { Coefficients }^{\mathrm{a}} \\
\text { Beta }\end{array}$} & \multirow[t]{2}{*}{$\mathbf{t}$} & \multirow[t]{2}{*}{ Sig. } \\
\hline & B & Std. Error & & & \\
\hline $\begin{array}{c}1 \\
\text { (Constant) }\end{array}$ & 3.544 & .526 & & 6.742 & .000 \\
\hline Agriculture & .283 & .117 & .451 & 2.424 & .024 \\
\hline
\end{tabular}

Table 2: Statistical analyses.

\begin{tabular}{|c|c|c|c|c|c|}
\hline \multirow[t]{2}{*}{ Model } & \multicolumn{2}{|c|}{$\begin{array}{l}\text { Unstandardized } \\
\text { Coefficients }^{\mathrm{a}}\end{array}$} & \multirow{2}{*}{$\begin{array}{c}\text { Standardized } \\
\text { Coefficients }^{\mathrm{a}} \\
\text { Beta }\end{array}$} & \multirow[t]{2}{*}{$t$} & \multirow[t]{2}{*}{ Sig. } \\
\hline & B & Std. Error & & & \\
\hline $\begin{array}{c}1 \\
\text { (Constant) }\end{array}$ & 4.107 & .392 & & 10.474 & .000 \\
\hline $\mathrm{MC}$ & .083 & .036 & .445 & 2.289 & .033 \\
\hline OC & -.079 & .033 & -.430 & -2.400 & .026 \\
\hline LS & .043 & .030 & .263 & 1.431 & .0256 \\
\hline
\end{tabular}

aDependent Variable: GDP.

Independent variable: Major crops + other crops + live stock.

MC: Major Crops; LS: Live Stock; OC: Other Crops

Table 3: Dependent variable: GDP growth rate.

poultry and such as live-stock. These factors are taken in our study which is contributing to agriculture sector that eventual cause to increase in the gross domestic product of Pakistan.

\section{References}

1. Ministry of Agriculture (2014) Agriculture Performance. Islamabad: Govt. of Pakistan.

2. Raza SA, Ali Y, Mehboob F (2012) Role of agriculture in economic growth of Pakistan. Munich Personal RePEc Archive pp: 1-8.

3. Ministry of National Food Security \& Research.

4. Ministry of Finance (2013-2014) Economic Survey of Pakistan. Overview of the Economy pp: 23-41.
5. worldbank.org (2014) World Bank Pakistan. World Bank Indicator Data. World Bank Pakistan

6. Zaman K, Khan MM, Ahmad M (2010) Assessing the Poverty Bias Growth Agriculture Sector. International Journal of Trade, Economic Finance 1: 303308

7. Adnan-Hye QM (2009) Agriculture on the Road to industrialisation and Sustainable Economic Growth. International Journal of Agricultural and Rural Development 2: 1-6.

8. Malik N (2010) Pakistan Agriculture Export Performance in the Light of Trade and Economic Reforms. World Journal of Agricultural Science 6: 19-38.

9. SBP (2014) State Bank of Pakistan. Karachi: SBP.

10. Adnan-Hye QM (2009) Money Supply and Agricultural Prices: A Causality Analysis for Pakistan Economy (Quarterly Data Analysis). Journal of Agricultural Research47: 2.

11. Livestock and Dairy Development Board.

12. Pakistan Agricultural Research Council.

13. Economic Survey of Pakistan (2014) Agriculture, Islamabad: Government of Pakistan.

14. Bhatti AM, Suttinon P, Nasu S (2009) Agriculture Water Demand Management in Pakistan. Society for Social Management Systems pp: 1-7.

15. Government of Pakistan (2013-2014) Budget, Islamabad: Ministry of Finance.

16. Agriculture Statistics of Pakistan.

17. ADB (2014) Asian Development Bank. Data, Asian Indicator. Asian Development Bank.

18. GOP (2014) Pakistan livestock Census. Agricultural Census Organisation.

19. Government of Punjab (2013-2014) Annual Report. Lahore: Punjab Agriculture Housee, Lahore.

20. Haq ZU, Gheblawi M, Muhammad S (2011) The Role of Global Economic Growth in Pakistan Agri Food Exports. Pakistan Institute of Development Economics, Islamabad, 50: 245-256.

21. Aslam DQ (NA) Problems in Agriculture of Pakistan. Lahore, Punjab, Pakistan.

22. Ayaz S, Hussain Z (2011) Impact of Institutional Credit on Production Efficiency of Farming Sector. Pakistan Economic and Social Review 49: 149-162.

23. Afzal N, Ahmad DS (2009) Agricultural Input Use Efficiency in Pakistan. Managing of Natural Resources for Sustaining Future of Agriculture 1: 1-12.

24. Pakistan Economic Survey 2013-14. 